\title{
Effects of bloom-forming cyanobacterial extracellular polymeric substances on the adsorption of cadmium onto kaolinite: behaviors and possible mechanisms
}

\author{
Xiaolin Kuang ${ }^{1}$, Jihai Shao ${ }^{1 *}$, Anwei Chen ${ }^{1}$, Si Luo ${ }^{1}$, Liang Peng ${ }^{1}$, Genyi Wu ${ }^{1}$ and Ji-Dong Gu ${ }^{2,3}$
}

*Correspondence: shao@

hunau.net

${ }^{1}$ College of Resources

and Environment, Hunan

Agricultural University,

Changsha 410128, People's

Republic of China

Full list of author information

is available at the end of the

article

\begin{abstract}
Cyanobacterial blooms result in high level of cyanobacterial extracellular polymeric substances (EPS) in water. The effects of bloom-forming cyanobacterial EPS on the distribution of $\mathrm{Cd}(\mathrm{II})$ in the interface between sediment and water is unknown. Clay is a main component in sediment. The effects of EPS, originated from a typical bloomforming cyanobacterium Microcystis aeruginosa, on the adsorption and desorption characteristics of $\mathrm{Cd}(\mathrm{II})$ by kaolinite were investigated in this study. Results of XRD analysis indicated that cyanobacterial EPS bound on the surface of kaolinite. The composite of kaolinite + EPS showed higher adsorption capacity toward $\mathrm{Cd}(\mathrm{II})$ than pure kaolinite, and hydroxyl groups were involved in the adsorption processes. The data for the adsorption of $\mathrm{Cd}(\mathrm{II})$ by kaolinite are well fitted by both Langmuir model and Freundlich model, whereas only Freundlich model well describes the adsorption data of $\mathrm{Cd}(\mathrm{II})$ by the composite of kaolinite + EPS. The adsorption of Cd(II) onto kaolinite was an exothermic process, but it became an endothermic process after EPS incorporation. Results of desorption showed that EPS incorporation increased the adsorption of kaolinite toward $\mathrm{Cd}(I)$ through physical adsorption, ion exchange and complexation.
\end{abstract}

Keywords: Microcystis aeruginosa, Extracellular polymeric substances, Cadmium, Kaolinite

\section{Background}

Heavy metal ions are toxic, non-biodegradable and can accumulate through food chain. Heavy metal pollution has caused serious ecological problems and posed a great health risk to human. Cadmium is a most hazardous heavy metal due to its high toxicity and carcinogenic effects (Son et al. 2012). In recent decades, industrial effluent and agricultural run-off caused widespread cadmium contamination in aquatic environments (Öztürk et al. 2009; Florian et al. 2011).

Another world wide water problem is the eutrophication and harmful algal blooms. Microcystis is a typical bloom-forming cyanobacterium. It frequently dominates in eutrophic fresh waters. Take China as an example, two large lakes, Lake Taihu and Lake Dianchi, were all received severe Microcystis based water blooms (Ye et al. 2009; Wu et al. 2014). Microcystis could maintain very high cell density in water during bloom 
formation stage. Ye et al. (2009) reported that the total cyanobacterial density (mainly as Microcystis) reached as high as $2.93 \times 10^{11}$ cells $/ \mathrm{mL}$ in Lake Taihu, China. Microcystis can excrete EPS into water. High cell density of Microcystis frequently results in high concentration of EPS in water column. Xu et al. (2013) reported that the EPS in cultures of Microcystis aeruginosa researched $130 \mu \mathrm{g}$ per $10^{7}$ cells. The main component of EPS in Microcystis culture is polysaccharides, and then followed by proteins (Xu et al. 2013). EPS enrich hydroxyl groups, carboxylic groups, acetylated amino, and also contain some noncarbohydrate constituents, e.g. phosphate and sulfate (De Philippis et al. 2011). These chemical groups in EPS can effectively bind with heavy metal ions through ions exchange or complexation (Gong et al. 2005; Fang et al. 2011).

Clay is a main component in sediment (Hou et al. 2013). Previous studies indicated that bacterial EPS could be absorbed by clays and sediments through hydrogen bonding and some other chemical bondings (Pierre et al. 2014; Cao et al. 2011; Fang et al. 2012). EPS addition changed the adsorption characteristics of heavy metal ions by clays, which in turn changed the concentration of heavy metal ions in water (Fang et al. 2010). The major part of heavy metal ions in aquatic environment is deposited in sediment through precipitation, sorption and complexation. The deposition of heavy metal ions from water column to sediment would decrease their concentration in water, and then decrease their bio-toxicity, and vice versa. Thus, studying on the transfer of heavy metal ions between water-sediment systems is crucial in evaluation of the ecological effect and the health risk of heavy metal contamination in aquatic environment.

The structures of EPS originated from different bacteria are different (Pereira et al. 2009). Though the effects of some bacterial EPS, e.g. originated from Pseudomonas putida, Bacillus subtilis, on the adsorption characteristics of heavy metal ions onto clays were studied (Fang et al. 2010; Mikutta et al. 2012), the effects of the EPS, originated from bloom-forming cyanobacteria, on the adsorption characteristics of heavy metal ions by clays remain unknown. In order to elucidate the transfer characteristics of $\mathrm{Cd}$ (II) in eutrophic water received cyanobacterial blooms, the effects of EPS originated from Microcystis on the adsorption and desorption characteristics of $\mathrm{Cd}(\mathrm{II})$ by kaolinite and their possible mechanisms were investigated in this study.

\section{Methods}

\section{Cyanobacterial strain, culture conditions, EPS extraction, and reagents}

Bloom-forming cyanobacterial strain $M$. aeruginosa NIES-843 was originated from the National Institute of Environmental Science, Japan, and was kindly provided by Professor Renhui Li (Chinese Academy of Sciences). M. aeruginosa NIES-843 was grown axenically in CT medium (Ichimura 1979) at $25 \pm 1{ }^{\circ} \mathrm{C}$ under a photoperiod cycle of 12:12 light/dark. The light intensity was set as $30 \mu \mathrm{mol}$ photons $/\left(\mathrm{s} \mathrm{m}^{2}\right)$. The cell free cultures of M. aeruginosa NIES-843 were collected at stationary phase by centrifuge at $10,000 \times g$ for $10 \mathrm{~min}$. The EPS in the cultures was purified in deionised water $(18 \mathrm{M} \Omega \mathrm{cm})$ using dialysis bags (1000-Da cutoff). The purified EPS solutions were dried using vacuum freezer, and then stored at $-20{ }^{\circ} \mathrm{C}$. $\mathrm{CdCl}_{2} \cdot 2.5 \mathrm{H}_{2} \mathrm{O}$ and other reagents used in this study were purchased from Sinopharm Group Chemical Reagent Ltd. (Shanghai, China), and were of analytical grade. 


\section{Preparation of kaolinite}

Kaolinite was purchased from Shanghai 54 Chemical Reagent Ltd (Shanghai, China), and it was further purified by washing with ethanol for 3 times, and then followed by washing with deionised water $(18 \mathrm{M} \Omega \mathrm{cm})$ for 3 times. The fractions of kaolinite, less than $2 \mu \mathrm{m}$, were prepared according to the method described by Cai et al. (2006).

\section{Adsorption experiments and adsorption isotherm}

Adsorption experiments were carried out in $10 \mathrm{~mL}$ centrifuge tube containing appropriate volume of deionised water $(18 \mathrm{M} \Omega \mathrm{cm}$ ), $30 \mathrm{mg}$ of kaolinite or the composite of kaolinite $(30 \mathrm{mg})$ and EPS. The suspensions of kaolinite and the composite of kaolinite + EPS were incubated on a shaker for $30 \mathrm{~min}$ with a speed of $120 \mathrm{rpm}$, and then appropriate mount of $\mathrm{Cd}(\mathrm{II})$ and supporting electrolyte $\left(\mathrm{KNO}_{3}\right.$, final concentration $0.01 \mathrm{M}$ ) were added into centrifuge tube, and the total volume was brought to $6 \mathrm{~mL}$ using deionised water. The centrifuge tubes were agitated on a shaker at a speed of $120 \mathrm{rpm}$ for $4 \mathrm{~h}$ (reached equilibrium). The $\mathrm{pH}$ value was set as 7 except $\mathrm{pH}$ experiments, and the temperature was set as $25^{\circ} \mathrm{C}$ except temperature experiments. In order to study the effect of EPS concentration on the adsorption of Cd(II) by kaolinite, the final EPS concentration was set as $0.1,0.3,0.6,1,2$, and $3 \mathrm{~g} / \mathrm{L}$, and the initial $\mathrm{Cd}(\mathrm{II})$ concentration was set as $5 \mathrm{mg} / \mathrm{L}$. In pH experiments, the $\mathrm{pH}$ value was set as $5,6,7$, and 8 , respectively, and the initial $\mathrm{Cd}$ (II) concentration was also set as $5 \mathrm{mg} / \mathrm{L}$. For determination of the effect of initial $\mathrm{Cd}$ (II) concentration on its adsorption by kaolinite and the composite of kaolinite + EPS, the initial Cd(II) concentration was set from 5 to $500 \mathrm{mg} / \mathrm{L}$, and the final EPS concentration in the treatment of kaolinite + EPS was set as $0.6 \mathrm{~g} / \mathrm{L}$. In temperature experiments, the temperature was set as $20,25,30,35$, and $40{ }^{\circ} \mathrm{C}$, respectively. After equilibrium, the suspensions were centrifuged at $12,000 \times g$ for $10 \mathrm{~min}$, and the $\mathrm{Cd}$ (II) in the supernatant was determined using atomic absorption spectrometer (Varian Techtron Pty. Ltd., Victoria, Australia). The amount of adsorbed Cd(II) was calculated from the differences between the initial $\mathrm{Cd}(\mathrm{II})$ concentration and the residual concentration after sorption. In order to study the adsorption isotherm of $\mathrm{Cd}(\mathrm{II})$ by kaolinite and the composite of kaolinite + EPS, adsorption data were fitted using Langmuir model and Freundlich model in linear form (Eqs. 1 and 2), respectively.

$$
\begin{aligned}
& \frac{1}{q_{e}}=\frac{1}{q_{\max } K_{L} C_{e}}+\frac{1}{q_{\max }} \\
& \ln q_{e}=\ln K_{f}+\frac{1}{n} \ln C_{e}
\end{aligned}
$$

where $q_{e}$ is the amount of adsorbate absorbed by adsorbent, $C_{e}$, the equilibrium concentration, $q_{\max }$, the maximum adsorption capacity upon monolayer saturation adsorbent, $K_{L}$, the constant related to the adsorption energy, and the $K_{F}$ and $\mathrm{n}$ are Freundlich parameters involved in the relative adsorption capacity and the affinity between adsorbent and adsorbate, respectively. 


\section{X-ray diffraction and Fourier transform infrared spectroscopy analysis}

The crystal structures of kaolinite and the composite of kaolinite + EPS were recorded using a XRD-6000 instrument (Shimadzu Seisakusho Ltd., Japan) employing graphite monochromatized $\mathrm{Cu} \mathrm{K} \alpha$ radiation, with scanning rate of $4^{\circ} / \mathrm{min}$ and ranging from $5^{\circ}$ to $75^{\circ}$. Fourier transform infrared (FT-IR) spectra of kaolinite and the composite of kaolinite + EPS were obtained on a spectrometer (PerkinElmer Spectrum 65, Perkin-Elmer Co., Norwalk, CT, USA).

\section{Desorption of $\mathrm{Cd}(\mathrm{II})$}

Desorption of $\mathrm{Cd}(\mathrm{II})$ from the kaolinite and the composite of kaolinite + EPS was performed using deionised water or $\mathrm{NH}_{4} \mathrm{NO}_{3}$ or EDTA as desorbent according to the methods previously described by Fang et al. (2011).

\section{Statistical analysis}

Statistical analysis was done by one-way ANOVA using SPSS (version 13.0, SPSS Inc., Chicago, IL, USA). Difference was considered to be significant at $P<0.05$ (LSD).

\section{Results}

\section{Effects of EPS on the adsorption of Cd(II) by kaolinite}

As indicated in Fig. 1, the EPS had a positive effect on the adsorption of kaolinite toward $\mathrm{Cd}(\mathrm{II})$. With the increase of EPS addition, the adsorbed Cd(II) increased. Compared with the control, the amount of adsorbed Cd(II) increased 6.95, 19.68, 36.85, and $44.60 \%$ at the EPS addition level of $0.1,0.3,0.6$, and $1 \mathrm{~g} / \mathrm{L}$, respectively. The positive effects of EPS on the adsorption of $\mathrm{Cd}(\mathrm{II})$ by kaolinite reached plateau phase at the addition level of $1 \mathrm{~g} / \mathrm{L}$.

\section{Characteristics of Fourier transform infrared spectroscopy}

The Vibrational spectra of EPS, kaolinite and the composite of kaolinite + EPS before and after $\mathrm{Cd}$ (II) adsorption, are shown in Fig. 2. The main absorption bands of EPS were corresponding to phosphorylated compounds $\left(1044 \mathrm{~cm}^{-1}\right)$, ring vibrations of polysaccharides $\left(1164 \mathrm{~cm}^{-1}\right), \mathrm{COO}^{-}$groups $\left(1410\right.$ and $\left.1618 \mathrm{~cm}^{-1}\right), \mathrm{C}=\mathrm{O}$ of amides $\left(1660 \mathrm{~cm}^{-1}\right)$, $\mathrm{C}=\mathrm{O}$ of $\operatorname{RCOOR}\left(1742 \mathrm{~cm}^{-1}\right), \mathrm{C}-\mathrm{H}\left(2936 \mathrm{~cm}^{-1}\right)$, and $\mathrm{O}-\mathrm{H}\left(3350-3470 \mathrm{~cm}^{-1}\right)$,

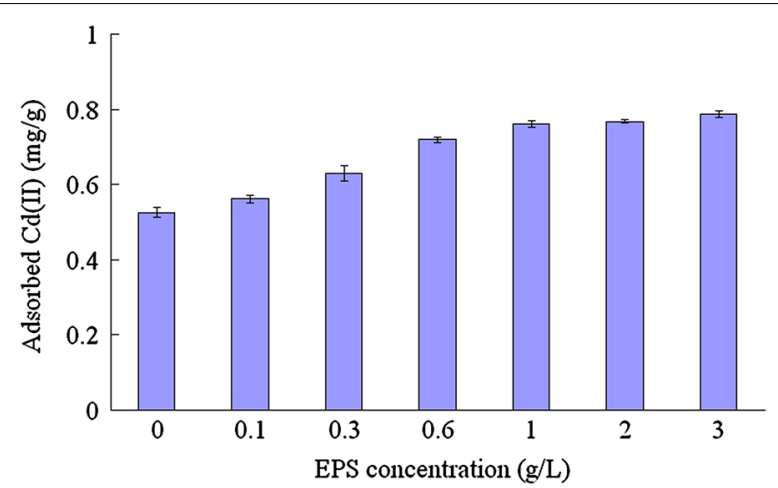

Fig. 1 Effects of cyanobacterial EPS on the adsorption of $C d(I I)$ by kaolinite. Data are presented as average value \pm standard deviation $(n=3)$ 


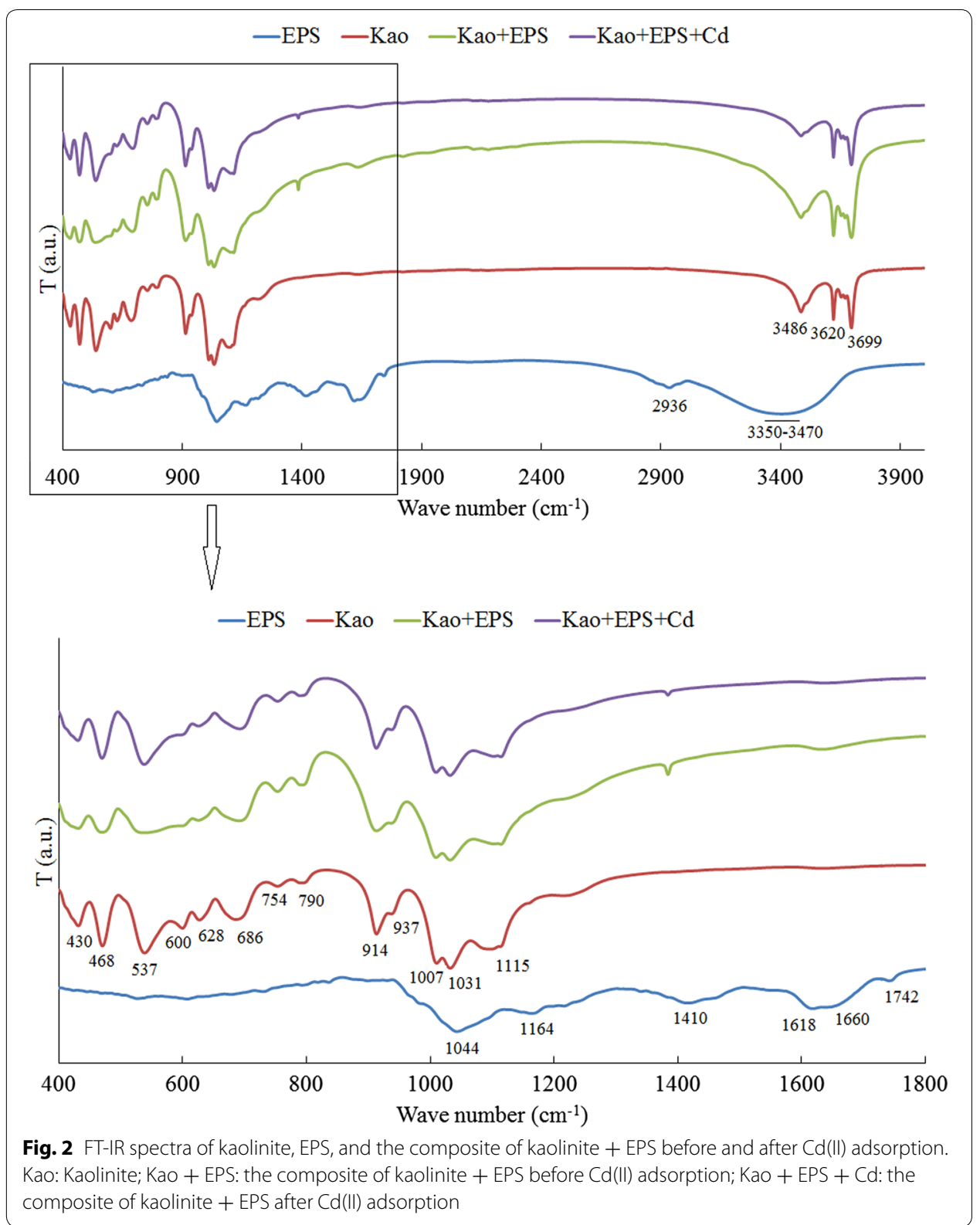

respectively. Typical frequency band corresponding to $\mathrm{Si}-\mathrm{O}\left(1115,1031,1007 \mathrm{~cm}^{-1}\right)$, $\mathrm{Al}-\mathrm{O}\left(430\right.$ and $\left.643 \mathrm{~cm}^{-1}\right)$, and $\mathrm{O}-\mathrm{H}\left(3486,3620\right.$ and $\left.3699 \mathrm{~cm}^{-1}\right)$ presented in kaolinite and the composite of kaolinite + EPS. No matter Cd(II) adsorption or not, the spectral features of the composite of kaolinite + EPS were exhibited a same pattern.

\section{Characteristics of X-ray diffraction}

Figure 3 shows the characteristics of X-ray diffraction of different treatments. The XRD pattern of kaolinite was similar with that of the composite of kaolinite + EPS. Typical diffraction peaks indexed as PDF\#29-1488 and PDF\#16-0409 for kaolinite presented in all treatments. EPS addition and Cd(II) adsorption did not change the diffraction patterns of kaolinite. 


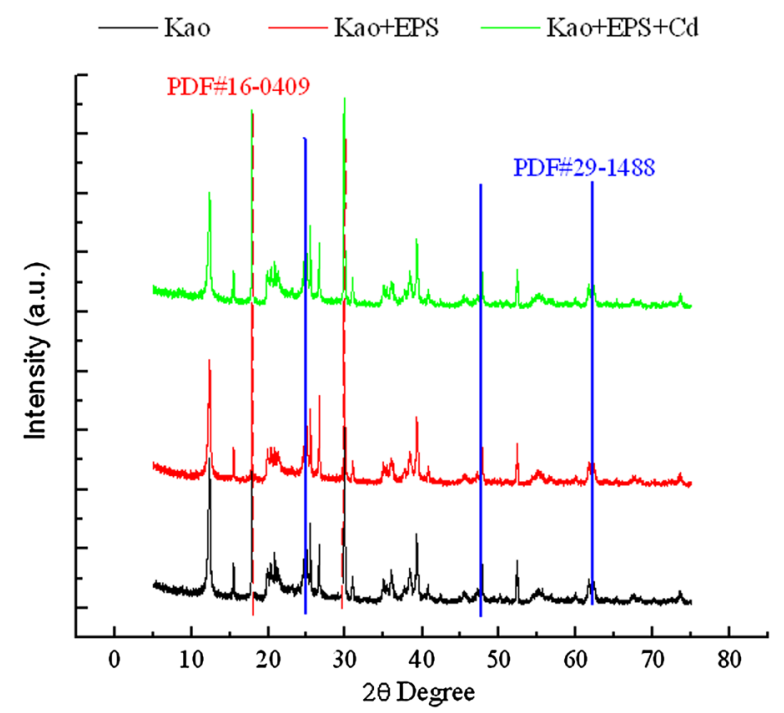

Fig. 3 XRD patterns of kaolinite and the composite of kaolinite + EPS before and after $\mathrm{Cd}(\mathrm{II})$ adsorption

\section{Effect of $\mathrm{pH}$ on the adsorption characteristics}

The adsorptions of $\mathrm{Cd}(\mathrm{II})$ by kaolinite and the composite of kaolinite + EPS were all significantly influenced by the $\mathrm{pH}$ value in the adsorption system (Fig. 4). With the increase of $\mathrm{pH}$ from 5 to 8 , the adsorptions of $\mathrm{Cd}$ (II) by all treatments continue to increase. EPS and $\mathrm{pH}$ value has a synergistic effect on the adsorption of $\mathrm{Cd}(\mathrm{II})$ onto kaolinite. Compared with the amount of adsorbed $\mathrm{Cd}(\mathrm{II})$ at $\mathrm{pH} 5$, the adsorbed $\mathrm{Cd}(\mathrm{II})$ by kaolinite increased $20.6 \%$ at $\mathrm{pH}$ 8, whereas it increased $47.5 \%$ under the condition of EPS addition at the level of $1 \mathrm{~g} / \mathrm{L}$ under this $\mathrm{pH}$ value.

\section{Different initial Cd(II) concentration and adsorption isotherm}

The adsorption of $\mathrm{Cd}(\mathrm{II})$ by kaolinite and the composite of kaolinite + EPS all increased with the increase of initial $\mathrm{Cd}$ (II) concentration (Fig. 5). The adsorption of $\mathrm{Cd}$ (II) by the composite of kaolinite + EPS was higher than that by kaolinite under the condition of a same initial $\mathrm{Cd}(\mathrm{II})$ concentration. In order to study the adsorption isotherm of $\mathrm{Cd}(\mathrm{II})$

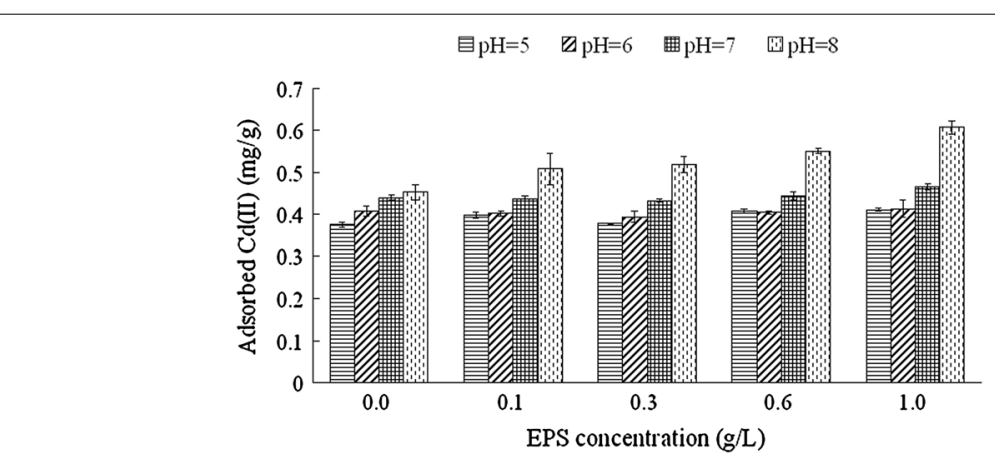

Fig. 4 Effects of pH on the adsorption of $\mathrm{Cd}(\mathrm{II})$ by kaolinite and the composite of kaolinite + EPS. Data are presented as average value \pm standard deviation 


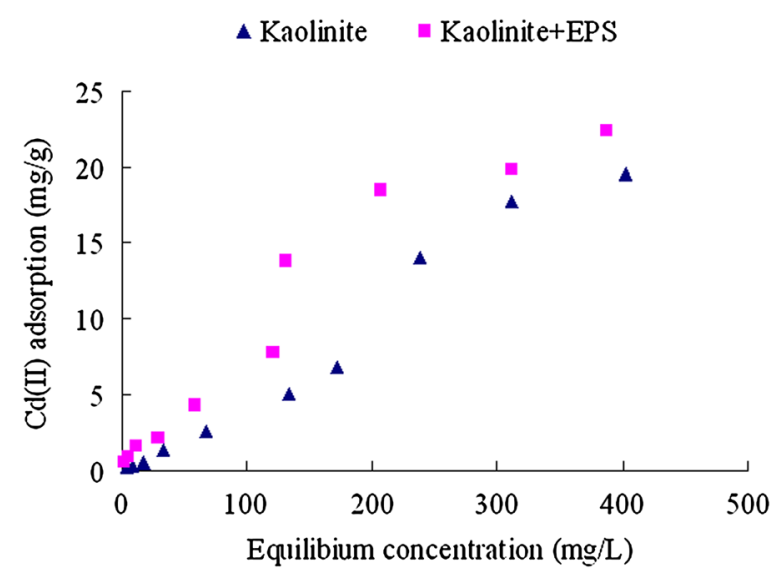

Fig. 5 Effects of initial $\mathrm{Cd}(\mathrm{II})$ concentration on its adsorption onto kaolinite and the composite of kaolinite + EPS. Data are presented as average value \pm standard deviation

by kaolinite and the composite of kaolinite + EPS, the adsorption data were fitted by Langmuir model and Freundlich model. As showed in Fig. 6 and Table 1, Both Langmuir model and Freundlich model were all well fitted by the adsorption data of kaolinite toward $\mathrm{Cd}(\mathrm{II})$ with a R square of 0.976 and 0.992 , respectively. As the adsorption of $\mathrm{Cd}(\mathrm{II})$ by the composite of kaolinite + EPS, the R square is 0.958 for Langmuir model and 0.972 for Freundlich model.
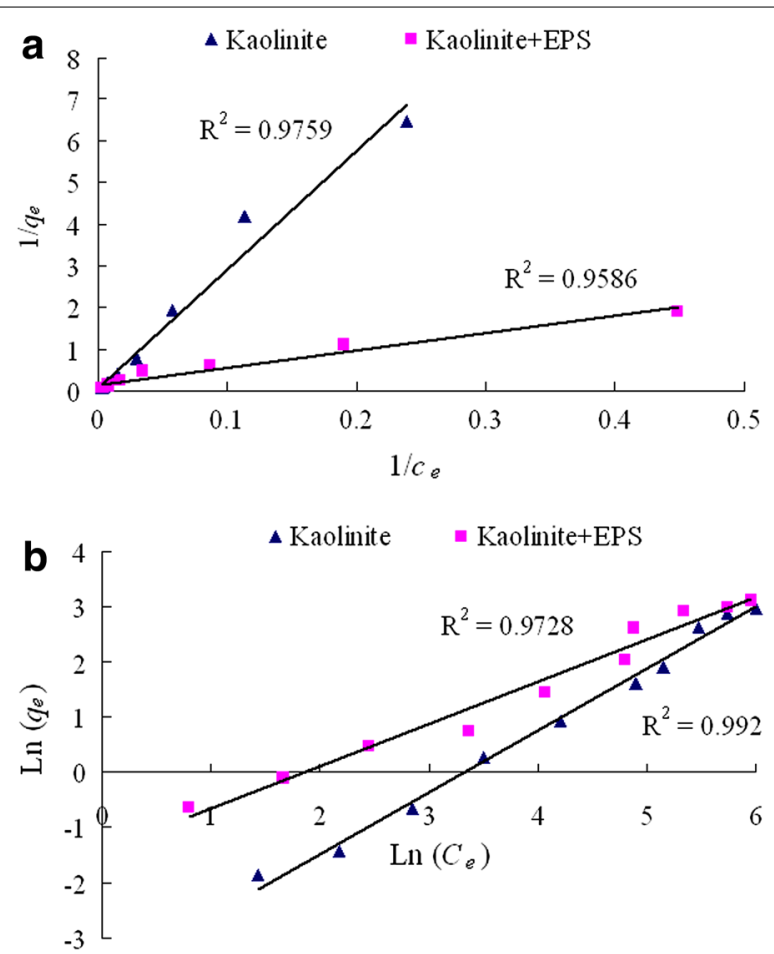

Fig. 6 Langmuir (a) and Freundlich (b) isotherm plots for $C d(I)$ adsorption by kaolinite and the composite of kaolinite + EPS 
Table 1 Parameters of Langmuir model and Freundlich model for the adsorption of Cd(II) onto kaolinite and the composite of kaolinite + EPS

\begin{tabular}{lllllllll}
\hline & \multicolumn{3}{l}{ Langmuir model } & & & \multicolumn{3}{l}{ Freundlich model } \\
\cline { 2 - 3 } & $\boldsymbol{q}_{\max }(\mathbf{m g} / \mathbf{g})$ & $\boldsymbol{K}_{\mathbf{L}}$ & $\mathbf{R}^{\mathbf{2}}$ & & $\boldsymbol{n}$ & $\boldsymbol{K}_{\boldsymbol{F}}$ & $\mathbf{R}^{\mathbf{2}}$ \\
\hline Kaolinite & 18.42 & 0.002 & 0.976 & & 0.89 & 0.02 & 0.992 \\
Kaolinite + EPS & 7.59 & 0.032 & & 0.959 & & 1.31 & 0.24 & 0.973 \\
\hline
\end{tabular}

\section{Effect of temperature on adsorption characteristics}

The effects of temperature on the adsorption of $\mathrm{Cd}(\mathrm{II})$ by kaolinite and the composite of kaolinite + EPS are shown in Fig. 7. The adsorption of Cd(II) by kaolinite was not obviously influenced by the temperature at a range from 20 to $35^{\circ} \mathrm{C}$. However, the amount of adsorbed $\mathrm{Cd}(\mathrm{II})$ at $40{ }^{\circ} \mathrm{C}$ decrease $5-6 \%$ when compared with those at $20-35{ }^{\circ} \mathrm{C}$. As for the composite of kaolinite + EPS, the adsorption toward $\mathrm{Cd}(\mathrm{II})$ was not obviously influenced at a range from 20 to $30{ }^{\circ} \mathrm{C}$, whereas it increased $7.4 \%$ at $35{ }^{\circ} \mathrm{C}$ and $8.7 \%$ at $40{ }^{\circ} \mathrm{C}$ when compared with that at $20^{\circ} \mathrm{C}$.

\section{Desorption characteristics}

Figure 8 shows the percentage of $\mathrm{Cd}(\mathrm{II})$ desorbed from kaolinite and the composite of kaolinite + EPS with different desorbents. Deionised water desorbed 9.31 and $14.72 \%$ of $\mathrm{Cd}$ (II) from kaolinite and the composite of kaolinite + EPS, respectively. The desorption ratio for $\mathrm{NH}_{4} \mathrm{NO}_{3}$ treatment was $16.03 \%$ for kaolinite and $26.31 \%$ for the composite of kaolinite + EPS. The desorption ratio of Cd(II) by EDTA was $18.32 \%$ for kaolinite and $30.60 \%$ for the composite of kaolinite + EPS.

\section{Discussion}

The results in this study showed that the EPS originated from M. aeruginosa increased the adsorption capacity of kaolinite toward Cd (II), and this positive effect increased along with the increase of EPS concentration in solution. Similar results were reported by Fang et al. (2010), who found that the composite of montmorillonite and EPS (from Pseudomonas putida) showed higher adsorption capacity toward $\mathrm{Cu}(\mathrm{II})$ than pure montmorillonite. Some previous studies showed that bacterial EPS could be absorbed

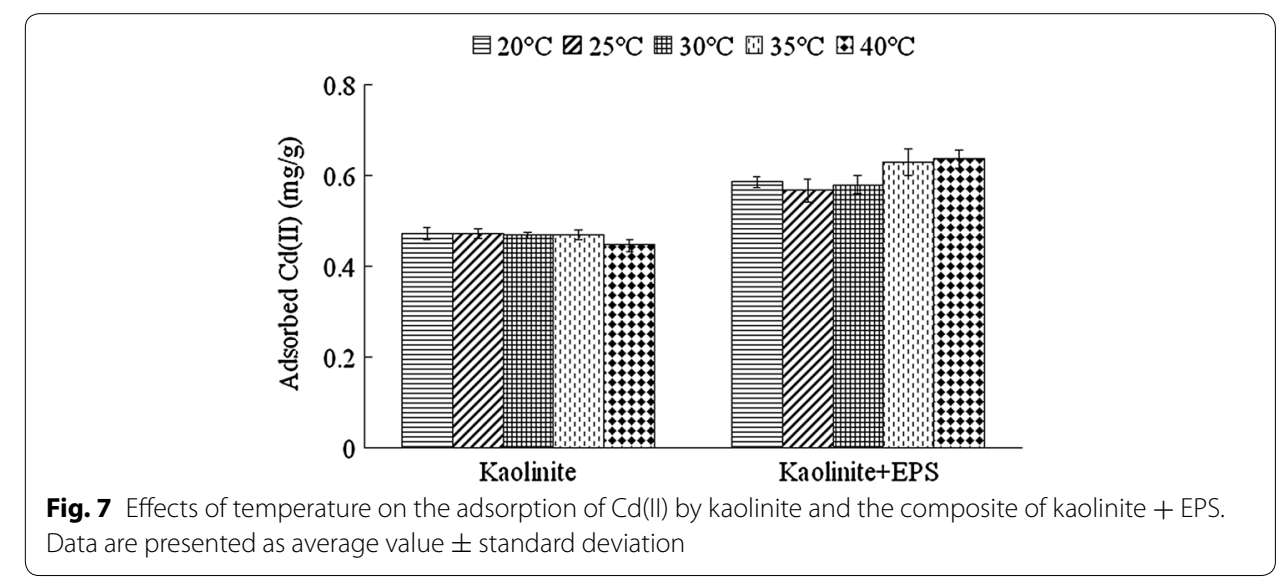




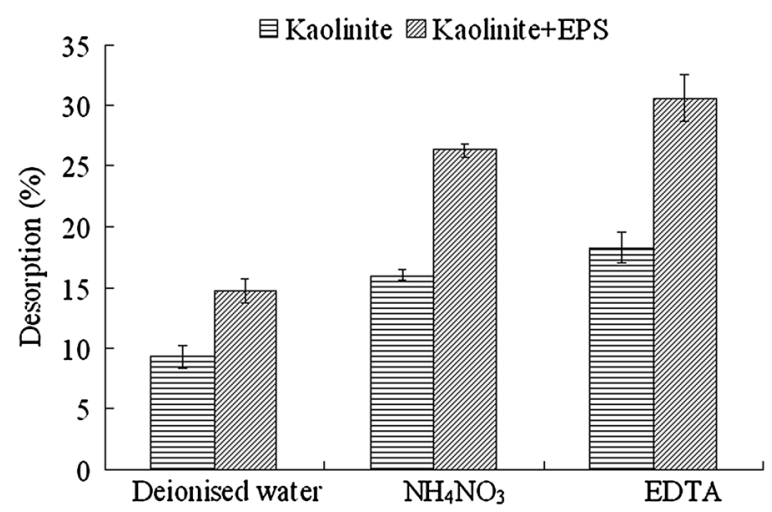

Fig. 8 Desorption ratio of $\mathrm{Cd}(\mathrm{II})$ from kaolinite and the composite of kaolinite + EPS using different desorbents. Data are presented as average value \pm standard deviation

by kaolinite, montmorillonite through hydrogen bonding (Cao et al. 2011; Mikutta et al. 2012). Bacterial EPS enrich hydroxyl groups, carboxyl groups, acetylated amino, and some other negative charged groups (De Philippis et al. 2011). These groups can effectively binding with heavy metal ions. Based on the results of FT-IR determination, a schematic diagram for the mechanism of positive effects of cyanobacterial EPS on the adsorption of $\mathrm{Cd}(\mathrm{II})$ by kaolinite were proposed and showed in Fig. 9. The groups like $\mathrm{PO}_{4}{ }^{3-},-\mathrm{COO}^{-},-\mathrm{CONH}_{2}, \mathrm{RCOOR}$, and $-\mathrm{OH}$ on the EPS may response for the positive effects of EPS on the adsorption of $\mathrm{Cd}(\mathrm{II})$ by kaolinite.

The interlayer spacing of kaolinite is $0.716 \mathrm{~nm}$. Only small high polar molecules can enter into the interlayer of kaolinite (Tang et al. 2015). The EPS are large bio-molecules. The size of EPS is far larger than the interlayer spacing of kaolinite. Results of XRD determination showed that cyanobacterial EPS addition and Cd(II) adsorption did not

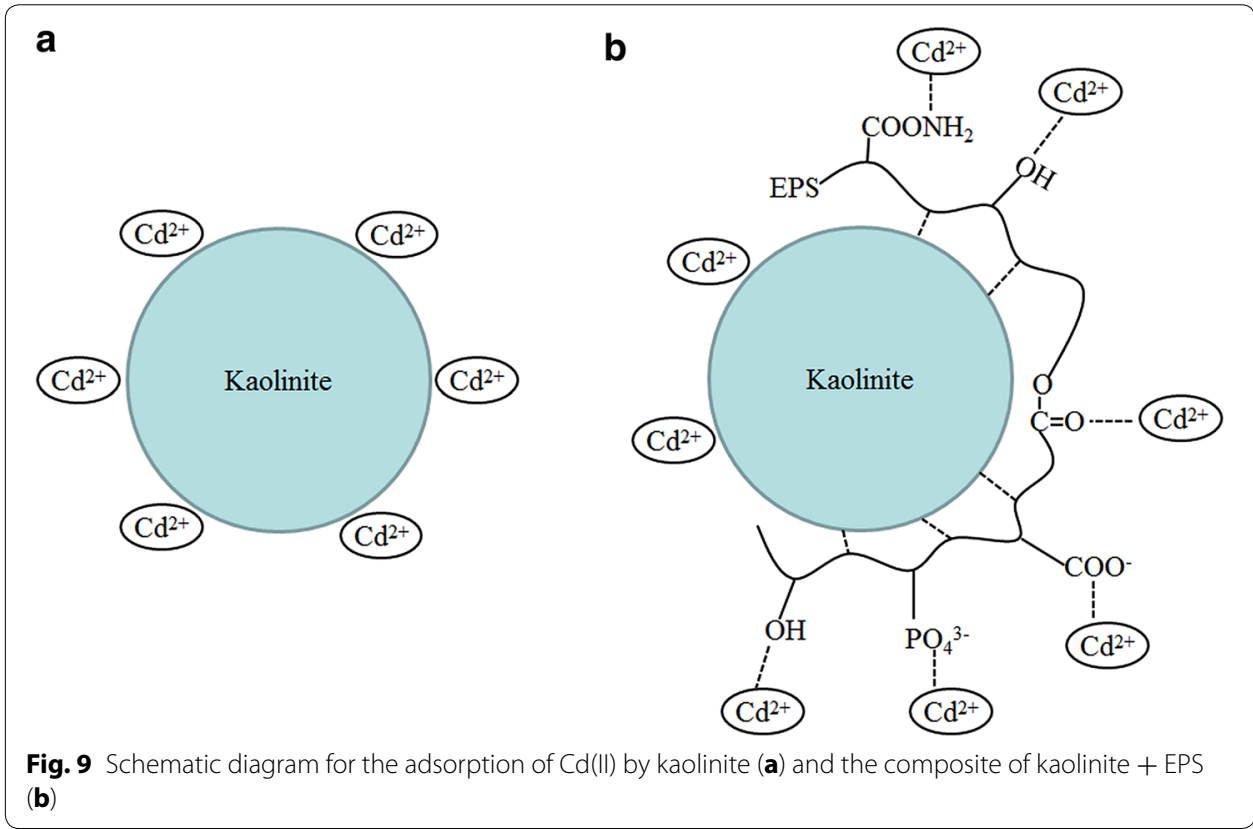


affect the diffraction patterns of kaolinite, indicating that the EPS and Cd(II) all bound on the surface of kaolinite and not intercalated into the interlayers.

The main absorption bands corresponding to $\mathrm{C}-\mathrm{O}, \mathrm{C}=\mathrm{O}$, and $\mathrm{O}-\mathrm{H}$ are presented in EPS in this study. They are in consistent with previous studies that polysaccharides are the main constituents of bacterial EPS (Xu et al. 2013). Compared with the vibrational spectra of kaolinite + EPS before Cd(II) adsorption, no new absorption band was found after $\mathrm{Cd}(\mathrm{II})$ adsorption for this treatment. However, we also noted that the vibration intensity of the band corresponding to - $\mathrm{OH}$ was strong in the treatment of kaolinite + EPS before Cd(II), but it became weak after Cd(II) adsorption. Thus, we deduced that hydroxyl groups were involved in the adsorption of $\mathrm{Cd}$ (II) by the composite of kaolinite + EPS.

Langmuir model is known as monolayer sorption, while the Freundlich model is suitable to multilayer sorption (He and Chen 2014). Our results indicated that both Langmuir model and Freundlich model were all well fitted by the data originated from the adsorption of $\mathrm{Cd}(\mathrm{II})$ by kaolinite, and the deduced $q_{\max }$ from Langmuir model was in consistent with experimental data. However, the adsorption isotherm of $\mathrm{Cd}(\mathrm{II})$ by the composite of kaolinite + EPS was only suitable to Freundlich model but not Langmuir model since the deduced $q_{\max }$ from Langmuir model was far lower than experimental data. Thus, we deduce that the addition of cyanobacterial EPS increased the heterogeneity on the surface of kaolinite. The parameter $n$ from Freundlich model reflects the affinity between adsorbent and adsorbate. The value of $n$ for the composite of kaolinite + EPS is higher than that of pure kaolinite, suggesting that the composite of kaolinite + EPS has higher affinity toward $\mathrm{Cd}(\mathrm{II})$ than pure kaolinite.

As for the thermodynamics of the adsorption of $\mathrm{Cd}(\mathrm{II})$ by kaolinite, previous studies gave complex and contradictory conclusions. For example, Sari and Tuzen (2014) reported that the adsorption of $\mathrm{Cd}(\mathrm{II})$ onto kaolinite was an exothermic reaction while it was described as an endothermic reaction by Angove et al. (1998). Results in this study supported the conclusion that it was an exothermic reaction since the increase of temperature decreased the adsorption of $\mathrm{Cd}(\mathrm{II})$ by kaolinite. As for the composite of kaolinite + EPS, the adsorption of $\mathrm{Cd}(\mathrm{II})$ by this composite increased along with the increase of temperature, and it exhibited as an endothermic process. The adsorptions of EPS toward $\mathrm{Pb}(\mathrm{II})$ and $\mathrm{Zn}(\mathrm{II})$ were reported as endothermic processes (Wang et al. 2013). Thus, we deduced that the adsorption of EPS on the surface of kaolinite response for the shift from exothermic process (kaolinite) to endothermic process (composite of kaolinite + EPS).

The fractions of $\mathrm{Cd}(\mathrm{II})$ desorbed by deionised water corresponding to physical adsorption ones (Fang et al. 2011). Ammonium nitrate could release the part of Cd(II) adsorbed by physical adsorption and ion exchange (Brady and Tobin 1995). EDTA could release the part of $\mathrm{Cd}(\mathrm{II})$ adsorbed through physical adsorption, ion exchange, and the complexation with carboxylic groups, acetylated amino and phosphate (Volesky and Holan 1995; $\mathrm{Li}$ et al. 2010). Compared with the treatment of pure kaolinite, the ratio of desorbed $\mathrm{Cd}(\mathrm{II})$ by $\mathrm{H}_{2} \mathrm{O}, \mathrm{NH}_{4} \mathrm{NO}_{3}$, and EDTA all increased in the treatment of kaolinite + EPS, suggesting that EPS addition increased the adsorption of $\mathrm{Cd}(\mathrm{II})$ by kaolinite through physical adsorption, ion exchange, and complexation. 


\section{Conclusion}

Cyanobacterial EPS bound on the surface of kaolinite. The composite of kaolinite + EPS showed higher adsorption capacity toward Cd(II) than pure kaolinite, and hydroxyl groups were involved in the adsorption process. The addition of cyanobacterial EPS increased the heterogeneity on the surface of kaolinite, and change the thermodynamics from exothermic process to endothermic one.

\section{Authors' contributions}

The experiments were conceived and designed by JS and JG. The experiments were performed by XK, SL and LP. The reagents/materials/analysis tools were provided by JS and GW. The manuscript was written by JS. All the authors read and approved the final manuscript.

\section{Author details}

${ }^{1}$ College of Resources and Environment, Hunan Agricultural University, Changsha 410128, People's Republic of China.

${ }^{2}$ Hunan Provincial Key Laboratory of Farmland Pollution Control and Agricultural Resources Use, Hunan Agricultural University, Changsha 410128, People's Republic of China. ${ }^{3}$ Laboratory of Environmental Microbiology and Toxicology, School of Biological Sciences, The University of Hong Kong, Hong Kong SAR, People's Republic of China.

\section{Acknowledgements}

The work was supported by the National Natural Science Foundation of China (No. 31470511); the Foundation of National Water Science and Technology Projects of China (2014ZX07206001-03); Foundation from Education Department of Hunan Province (14B084).

\section{Competing interests}

The authors declare that they have no competing interests.

Received: 14 October 2015 Accepted: 20 April 2016

Published online: 27 April 2016

\section{References}

Angove MJ, Johnson BB, Wells JD (1998) The influence of temperature on the adsorption of cadmium(II) and cobalt(II) on kaolinite. J Colloid Interface Sci 204(1):93-103

Brady JM, Tobin JM (1995) Binding of hard and soft metal ions to Rhizopus arrhizus biomass. Enzyme Microb Technol 17(9):791-796

Cai P, Huang QY, Zhang XW (2006) Microcalorimetric studies of the effects of $\mathrm{MgCl}_{2}$ concentrations and $\mathrm{pH}$ on the adsorption of DNA on montmorillonite, kaolinite and goethite. Appl Clay Sci 32(1-2):147-152

Cao Y, Wei X, Cai P, Huang Q, Rong X, Liang W (2011) Preferential adsorption of extracellular polymeric substances from bacteria on clay minerals and iron oxide. Colloids Surf B 83(1):122-127

De Philippis R, Colica G, Micheletti E (2011) Exopolysaccharide-producing cyanobacteria in heavy metal removal from water: molecular basis and practical applicability of the biosorption process. Appl Microbiol Biotechnol 92(4):697-708

Fang L, Huang Q, Wei X, Liang W, Rong X, Chen W, Cai P (2010) Microcalorimetric and potentiometric titration studies on the adsorption of copper by extracellular polymeric substances (EPS), minerals and their composites. Bioresour Technol 101(15):5774-5779

Fang L, Wei X, Cai P, Huang Q, Chen H, Liang W, Rong X (2011) Role of extracellular polymeric substances in Cu(II) adsorption on Bacillus subtilis and Pseudomonas putida. Bioresour Technol 102(2):1137-1141

Fang L, Cao Y, Huang Q, Walker SL, Cai P (2012) Reactions between bacterial exopolymers and goethite: a combined macroscopic and spectroscopic investigation. Water Res 46(17):5613-5620

Florian T, Graham ND, Chiaradia M, Arpagaus P, Wildi W, Poté J (2011) Local to regional scale industrial heavy metal pollution recorded in sediments of large freshwater lakes in central Europe (lakes Geneva and Lucerne) over the last centuries. Sci Total Environ 412-413:239-247

Gong R, Ding YD, Liu H, Chen Q, Liu Z (2005) Lead biosorption by intact and pretreated Spirulina maxima biomass. Chemosphere 58(1):125-130

He J, Chen JP (2014) A comprehensive review on biosorption of heavy metals by algal biomass: materials, performances, chemistry, and modeling simulation tools. Bioresour Technol 160:67-78

Hou J, Wang C, Wang P, Qian J (2013) Temporal variability and spatial distribution of granulometric composition of surface sediments and elassification in Taihu Lake. J Hohai Univ (Nat Sci) 41:114-119

Ichimura T (1979) Media for freshwater cyanobacteria. In: Nishizawa K, Chihara M (eds) Methods in phycology. Kyouritsu Shuppan, Tokyo, pp 295-296

Li Y, Yue QY, Gao BY (2010) Adsorption kinetics and desorption of $\mathrm{Cu}(\mathrm{II})$ and $\mathrm{Zn}(\mathrm{II})$ from aqueous solution onto humic acid. J Hazard Mater 178(1-3):455-461

Mikutta R, Baumgärtner A, Schippers A, Haumaier L, Guggenberger G (2012) Extracellular polymeric substances from Bacillus subtilis associated with minerals modify the extent and rate of heavy metal sorption. Environ Sci Technol 46(7):3866-3873

Öztürk Ş, Aslım B, Türker AR (2009) Removal of cadmium ions from aqueous samples by Synechocystis sp. Sep Sci Technol 44:1467-1483 
Pereira S, Micheletti E, Zille A, Santos A, Moradas-Ferreira P, Tamagnini P, De Philippis R (2009) Compositeityof cyanobacterial exopolysaccharides: composition, structures, inducing factors and putative genes involved in their biosynthesis and assembly. FEMS Microbiol Rev 33(5):917-941

Pierre G, Zhao JM, Orvain F, Dupuy C, Klein GL, Graber M, Maugard T (2014) Seasonal dynamics of extracellular polymeric substances (EPS) in surface sediments of a diatom-dominated intertidal mudflat (Marennes-Oléron, France). J Sea Res 92:26-35

Sari A, Tuzen M (2014) Cd(II) adsorption from aqueous solution by raw and modified kaolinite. Appl Clay Sci 88-89:63-72

Son YO, Wang L, Poyil P, Budhraja A, Hitron JA, Zhang Z, Lee JC, Shi X (2012) Cadmium induces carcinogenesis in BEAS$2 B$ cells through ROS-dependent activation of PI3 K/AKT/GSK-3B/B-catenin signaling. Toxicol Appl Pharmacol 264(2):153-160

Tang WF, Gu XY, Zhang S, Yuan HF, Jiang Y, Zhao JR (2015) Preparation and characterization of kaolinite-potassium dihydrogen phosphate intercalation composite. Spectrosc Spectr Anal (Chin J) 35:462-465

Volesky B, Holan ZR (1995) Biosorption of heavy metals. Biotechnol Prog 11(3):235-250

Wang L, Yang J, Chen Z, Liu X, Ma F (2013) Biosorption of Pb(II) and Zn(II) by extracellular polymeric substance (Eps) of Rhizobium Radiobacter: equilibrium, kinetics and reuse studies. Arch Environ Prot 39(2):129-140

Wu Y, Li L, Gan N, Zheng L, Ma H, Shan K, Liu J, Xiao B, Song L (2014) Seasonal dynamics of water bloom-forming Microcystis morphospecies and the associated extracellular microcystin concentrations in large, shallow, eutrophic Dianchi Lake. J Environ Sci 26(9):1921-1929

Xu H, Cai H, Yu G, Jiang H (2013) Insights into extracellular polymeric substances of cyanobacterium Microcystis aeruginosa using fractionation procedure and parallel factor analysis. Water Res 47(6):2005-2014

Ye W, Liu X, Tan J, Li D, Yang H (2009) Diversity and dynamics of microcystin — producing cyanobacteria in China's third largest lake, Lake Taihu. Harmful Algae 8(5):637-644

\section{Submit your manuscript to a SpringerOpen ${ }^{\odot}$ journal and benefit from:}

- Convenient online submission

\section{Rigorous peer review}

- Immediate publication on acceptance

- Open access: articles freely available online

- High visibility within the field

- Retaining the copyright to your article

Submit your next manuscript at $\boldsymbol{\nabla}$ springeropen.com 